Часлав В. Николић*

Универзитет у Крагујевцу

Филолошко-уметнички факултет

Катедра за српску књижевност

https://doi.org/10.18485/ai_zsjoski.2019.2.ch3

821.163.41.09-31 Црњански М.

811.163 .41

\title{
СРПСКИ ЈЕЗИК МОЖЕ ДА ГОВОРИ: КЊИЖЕВНА ФОРМУЛАЦИЈА ЈЕЗИКА У РОМАНУ О ЛОНДОНУ МИЛОША ЦРњАНСКОГ
}

Поетику Милоша Црњанског обележава искуство перманентног кретања и промене у језику, што је и један од рефлекса промена у савременом искуству. Језик у Роману о Лонgону посматрамо, у овом раду, као израз епохалног максимума до којег су се српски језик и осећајност српске културе развили. Као пример овог развоја препознајемо и специфичну динамику у приповедању Црњанског, према којој се синтаксичке и онтолошке позиције субјекта и објекта у истој реченици преиначавају у функцијама, па субјект постаје објект, док се објект трансформише у субјект. У реченици Црњанског приметно се кристалише оно што је и предмет приповедања: град као субјект подвлашћује и празни бића, која се, не препознајући онтолошко усмерење својих прилагођавања, преображавају у објекте.

Кључне речи: језик, књижевност, норма, субјект, објект, реченица, прича

\footnotetext{
* caslav.nikolic@filum.kg.ac.rs

1 Овај рад је део истраживања која се изводе на пројекту 178018

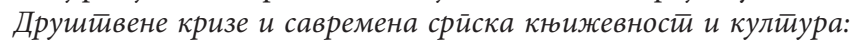
национални, реїионални, евройски и ілобални оквир који финансира Министарство просвете и науке Републике Србије.
} 
1.

Језик Милоша Црњанског у Роману о Лондону, његовој завршној, а у тематском, симболичком, метафизичком и поетичком смислу заокружујућој, књижевној структури, доследно испољава естетски самоодређујућу и несравњиву природу овог писца, јер збраја најуспелије ефекте стваралачког становишта Црњанског. Становишта према коме књижевни израз целим спектром својих могућности легитимише поетику аутора, постајући и резултанта уноса уметничке тенденције у језик и облик његове аутентичне песничке формулације. Свестан дуге историје запитаности, сумњи, отклона и подсмеха у вези са својствима свог језика, Црњански је 1973. године његово препознавање двојако уоквирио: егзистенцијално-културним и естетичко-поетичким одлукама. У шире захваћеном пространству породичних традиција и егзистенцијалног самоосећања Црњански је у свом језику налазио йослеguиу живота, те се о том језику и не може рећи боље до да је он, како га је велики писац разумео, једно кретиане: „[...] кретање од Темишвара, где се није говорило чисто српски, али се у мојој породици говорило чисто српски, па кретање до Београда и даље, живота мог, који је везан за земљу био, па сам према томе и говорио тако" (Црњански 2004: 689). Као рефлекс естетичког опредељења, Црњански је градио особени језик, јер то што је била, у форми говора, предаја коју су уредили живот и историјско-културно кретање писац преудешава, ствара од ње нешто несводиво на саму ту предају. Мада је „наш свет навикао на један врло једноставан језик", свикнутом једнолику и беспрекидности културног стандарда он противставља други, изражајнији, многодимензионалнији, музички разуђен и усталасан дизајн, јер и „српски језик може да 'свира', да говори и да буде врло интересантан језик” (Црњански 
2004: 690). Писац тематске монументалности и велике културолошке разуђености јесте и писац изразите поетичке променљивости, чији „онтолошки несклад са светом" - у којем су и Црњански по свом егзистенцијалном положају и његови јунаци по свом епохалном предодређењу - појачава мисао о томе да је дух тога писца, како увиђа Мило Ломпар, идиоритмички, јер, као самотник, „дише дисхармонично и атонално”, па и у литератури значења и језик изокреће „на радикалан начин” (Ломпар 2018: 465). Ако Вук није имао потребу „да се читаоцу наметне воља писца”, те су његове реченице „биле једноставне и вама је цела, дуга реченица, без тачака, запета, могла да буде разумљива", онда поствуковски тоналитет у казивању о језику не значи да Црњански негира вуковску парадигму у контексту њене епохалне устројености, већ се, уважавајући њен епохални домет, отвара захтеву властите епохалности и настоји да његов језик не буде Вуков језик јер би требало да буде такав какав „у модерном добу”, као ехо деликатне епохе, „ви морате да дајете” (Црњански 2004: 689). Наступајући са позиција радикалног (авангардног) модернизма, Црњански, насупрот традиционалном модернисти Андрићу, чијем је тону доследно својствена хармонија, проблематизује језичку норму београдског стила, особито њен рефлекс у облику „лоїики уређене реченице” и, најуочљивије посредством запета, но не и само преко њих, преуређује израз тако да га измешта „изван или изнаg логике”, чиме одругојачује и обогаћује језик. (Ломпар 2018: 422). Ипак, колико је рефлекс промењене, усложњене, неразумљиво замршене природе саме савремености, то што се у коначном свом уобличењу испоставља као језик Црњанског више је од сеизмографије времена и манифестног обавезивања поетички профилисане групе, пошто воља писца није само у томе шта он, спрам атмосфере једног доба, мора да даје, будући будан, дакле одговоран пред силама које 
склапају епоху, већ пре свега у томе шта он као сасвим посебан смисао, формулацију, уметничку тенденцију у језик савремености може да уноси - будући бесвестан за све друго онда када је слободан да чује како „поезија говори” (Црњански 2004: 689). У писму Јулију Бенешићу, 1918. године, Црњански изражава намеру да свој језик тако измеша, како у њему не би било „ничег што би га дало назвати екавски, штокавски, босански” (Ломпар 2018: 501). Одлука о синтези већ тада предосећа историјско, тематско и стилско продубљивање и заокружење национално-светског регистра у позним романима, али представља и одлуку да се властити књижевни дискурс успостави у естетичкој, метајезичкој, семиотичко-симболичкој, а не у нормативној перспективи: „Лепота језика је у знаку, у мистичној боји речи, а не у чистоти и ја ћу до смрти радије писати тица - но птица." (Ломпар 2018: 501) Налик томе што, по Борису Успенском, икона као знаковна суштина „изражава и одређује теолошку суштину иконе”, док схваћене прагматички, по језичкој функцији, иконе, по светоотачком учењу, „имају исту улогу за неписмене коју и књиге за писмене” (Успенски 1979: 252-253), и Милош Црњански ослобађа језик прагматичких обавеза, осамостаљује знак и изражава његову естетичку суштину.

2.

Језик у Роману о Лондону Милоша Црњанског аутентичан је пример епохалног максимума до којег су се српски језик и осећајност српске културе развили. Зачудним смисаоним променама, сижејно и симболички далекоциљним парентезама, хијастичким премештањима и спреговима, Црњански у минијатури језичког организовања приказује целину приповедног смисла удешеног према 
„огромности и гломазности Лондона”. Успостављајући широко платно - најшире у српској књижевности - као обухватну визију историје и времена, Црњански показује „изузетну способност да у једном језичком елементу, готово иконографски, преокрене структуру великог платна: то му омогућава његова језичка (не граматичка) виртуозност" (Ломпар 2008). У деликатној приповедној синтакси Црњанског већ је примећена промена фокализације - унутар самоосећања истог јунака остварује се и поглед изнутра и поглед на себе, као на објект посматрања, споља (Петковић 1996) - као што је у парентезама учињено померање од основног хронотопа како би се покренуле извесне културно-историјске асоцијације и увели додатни смисаодавни знакови. Промена перспективе „из које су предочени приповедне ситуације и догађаји” (Принс 2011: 54) омогућава и то да се, у једној реченици остварени као такви, субјект и објект, у истом, премда веома продуженом, многоспратном и многодомном реченичном периоду, преиначе у функцијама и да постану оно друго: субјект погледа да постане објект гледања, а објект да се трансформише у субјект. Дуг и сложен реченични период којим се - у виду свеобухватног питања о огромној и смртоносној вароши, безмерној Сфинги, милионима људи и њиховој потрази за срећом и смислом - довршава уводно поглавље последње књиге Црњанског синтаксички и смисаодавно оличава то што је и предмет Романа о Лондону: град као субјект подвлашћује и празни бића, а ова се, не дочувши вршак налога за урбаним прилагођавањем, својевољно преображавају у објекте. Степенујући, универзализујући и изоштравајући га, приповедач Црњанског приступа предмету приче, на крају „Прве главе романа”, тако да сваки степеник тог узвођења оцрта и оне предмете преко чијих се судбина открива и онтолошко устројство представе у којој врхуни тема. Отуда прича која почиње у тре- 
нутку када је јунак „енглеским звекиром, почео да куца у врата и да, потмуло, дозива: „Нађа, Нађа!” ипак није само прича „о том човеку у Лондону, и његовој жени, не само о њиховој љубави, него и другим Русима, који су стигли били у Лондон, пре њих, пре много година” (Црњански 2004: 19). Но не и само о њима, расељеним лицима, „него и о том лондонском свету, кога, као сардине у лименим кутијама, возе, ујутру, на рад, у Лондон, а враћају увече, окренуте леђима према Лондону, из Лондона" (Црњански 2004: 19-20). Када се стрелица препознавања приповедног средишта помери од појединачног субјекта до обухватне перспективе и персоналности урбаног света у целини, Црњански саопштава о институту једног објекта, неприкосновеног, у средишту симболизације и светско-историјског ритма, безгласном и неприступном сваком хуманистичком осмишљавању:

„А највише о тој, огромној, вароши, чији је загрљај био смртоносан за толико људи и жена, - а која све то гледа, нема, као нека безмерна Сфинга, која слуша како пролазник за пролазником пита: „Где је ту срећа? Каквог, тај улаз и излаз пролазника, у самоћи, и гомилама, - четири, осам, четрнаест милиона? - има смисла?" (Црњански 2004: 20)

Прича осмишљава то у вези са чим је, због неупоредиве огромности наративног предмета, проширен распон причања. Ипак, то што се на почетку реченице објективизује - као приповедном оку наспрамна огромна и смртоносна варош - у парентези је преокренуто, па је $\bar{u} а$ варош метафорички и митолошки пробуђена, субјективизована. Док је испрва она била „све то” што треба видети како би се разумела смрт, огромност полиса запоседа тачку гледишта, па се из новог средишта пројекције, поунутрашњеног овом огромношћу, гледа „све то” што су постали људи као ефекти умирања. 
Ако то што Сфинга „слуша” питања пролазника омогући да та питања, као завршни део исте обухватне реченице, у њеном новом и изоштравајућем рефлексу, пролазници и изговоре, њихов говор не враћа им првенство субјекта у онтолошком смислу. Јер то како Сфинга гледа и слуша одређује и то како, сами за себе, постоје они који пред њу долазе. Не само да о срећи пита „пролазник за пролазником", већ су и у питању о властитом смислу они себи постали објективни: они који, поставши други, сносе судбину свога пролажења. Ако питајући о смислу пролажења сугеришу да нису апсолутно удаљени од свога ja, изостајање одговора на питање о таквом удаљавању показује да су кључеви њихове судбине припали ономе што их посматра и слуша, али на начин изостајања знања које би откључало чудесну загонетку и променило однос великог објекта и човека/субјекта. Евиденција милиона пролазника, као трајно потчињених питању без одговора показује да је у искуству пролажења преовладало нешто ново, нешто изван субјективности.

Духовноисторијски профил модерности неодвојив је од напора и воље „субјекта да се постави у трансцендентално средиште света, и да мисли о себи као о универзалној узрочности”, да се, дакле, узрочно претпостави кроз владу „једног закона чији господар остаје он”, а ипак, док истовремено затеже тетиве које треба да га узвласте и центрирају, субјект „кришом призива објект”, чији је исход један „облик преокретања каузалности” и стање „жестоког криволиптања субјективности” (Бодријар

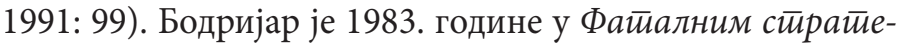
іијама описао оно што је, као средиште приповедне ситуације Романа о Лондону, Милош Црњански 1971. године, у економским, политичким, културолошким, језичким и онтолошким одјецима судбине руске емиграције, избегле у престоницу британске империје, кондензовао као књижевно осећање фаталног премета у историји субјекта. 
Приповедни призор и није о руском брачном пару који је у преплету контекстуалних, метафизичких и егзистенцијалних претпоставки њиховог брака одбранио одлуку за своју заједницу и потврдио епохалну релевантност и одрживост међуљудског поуздања, већ о духу, ритму и смеру светскоисторијског кретања у тамном озрачју Лондона, који је два бића раздвојио, променио и уклонио из нашег знања. Није реч о ситуационо условљеној, већ о епохално устројеној судбини, јер „свака судбина субјекта прелази у објект”, па је „на место универзалне каузалности”, какву је просветитељска идеологија зајамчила субјекту, иронија модернистичког пројекта открила „фаталну моћ једног појединачног објекта" (Бодријар 1991: 100). Роман Црњанског кристализује свест о неодрживости позиције субјекта, па се и језик овог писца престројава, његова се реченица усложњава, лавиринтално расте, усмерава се многим предметним адресама, креће се по површини основне предметности романа и по дубини евоцираних резонанци, а у том богатом и дугом кретању она уздрмава стационарност својих елемената, преокреће њихову каузалност, па је облик реченице Црњанског, каква је она о граду-сфинги, постао простор сталне, универзално узроковане али и манифестно инверзне субјекитивизације и објектиивизације. Волшебно се нашавши у Лондону, Рјепнин осећа како је једина жеља тог града-објекта да буде „судбина другог”, дакле и судбина Рјепнинова, те да и за юеīa постане „догађај који превазилази сваку субјективност", догађај који - како Роман о Лонgону предестинира и појачава Бодријарову мисао - поражава субјекта и ослобађа га „његових циљева, његове присутности и свих одговорности према себи и према свету" и тако чини да га најзад, када је мисао о самоубиству постала видљиви корак у своје невидљиво поноћно испуњење, признамо „у једној страсти која је најзаg gефинитиивно објекииивна" (Бодријар 1991: 99). 
Ако су масе „моћне због њихове ћутње” (Бодријар 1991: 99), онда моћ прећутаног у томе што „четири милиона душа станује у Лондону, а осам у ширем Лондону" заправо и није њихова моћ, јер се објективизује у једној издигнутијој и широј, надперсоналној равни, у којој се види како „у ствари, четрнаест милиона душа ухваћено је у мрежу Лондона" (Црњански 2004: 15). То што су милиони ухваћени у урбаној мрежи модерности, те свака појединачна gуша „живи око Лондона, долази у Лондон, пролази, ради, нестаје у Лондону, а нико никог не зна, у том астрономском конгломерату" (Црњански 2004: 15) не двоуми хоће ли душе које се не препознају бити себи оgyзетее. Као што је и Рјепнин на крају прве књиге Романа, враћајући се са летовања у град као у вавилонски лавиринт и примећујући колико, премда се баш $\bar{u} о$ не чује, „дише тешко, као од рвања, - са Лондоном, - а осећа, како га неко дави, и како и он, да дави, покушава", у свом духу изоштрио и осећање да то што му приносе „мала колица на точковима, за инвалида" (Црњански 2004: 345), јер му је на летовању пукла Ахилова тетива, многостепено, не тек анатомски, значи да је и сам постао узети. Као што је у свом самоприказивању Нађи сазнање о узетости призвао у његовој онтолошки превратној последици, тиме што га је, прећуткујући супрузи колоплет тамне мисаоности који је окружио његову озледу, подредио моћи $\hbar y \bar{u}$ ヶе, као налогу нечег извањског што је запосело перспективу унутрашњег одлучивања. Рјепнин, дакле, ћути, али у њему зато нема моћи, као што ни суштинска ућутаност милиона у Лондону, смисаона безвредност многог брбљања или сабијање говора у елементарне, кратке, аутоматизоване, неаутентичне поздраве, као једно опште склизавање у тишину, не дозвољава да моћ буде $\bar{w} y$, у душама милиона, већ у граду самом, као у објекту чија је моћ-и-ћутиғьа уистину суверена и који, остављајући сва питања без задовољења, привилегује себе-тишину. Лон- 
дон-Сфинга не одговара на питања, али она та питања слуша, чиме управо нараста моћ објекта, који непрестано заводи одсутношћу своје жеље, дакле аутентичним ћутањем, разиграва и надиграва жељу код својих субјеката, „изазива [je] или гаси, распаљује или обмањује” (Бодријар 1991: 97). Однос се преокреће и субјект не може да задржи „апсолутну привилегију”, јер ћутња заводи душе које нешто, као одговор о властитом смислу, желе, а тиме утврђује град-објекат, као што истовремено појачава и празни жељу и питања о властитој смислености, дакле развлашћује субјекте. Премда се, уласком у 20. век, могло учинити да је објект „оно што је ишчезло на хоризонту субјекта”, тај век је, као зрење и колапс модерности, показао да „са дна овог ишчезнућа он (објект) обухвата субјект у своју фаталну стратегију” и чини да, као усамљена душа на позорју мегалополиса, „субјект ишчезава на хоризонту објекта" (Бодријар 1991: 99).

3.

Милош Црњански не уприсутњује језиком тек оно што је юеі̄ово у биографском, контекстуалном, историјском или културолошком промеру човековог самопосматрања, или оно што је наше у лингвистичком и нормативном подразумевању, већ оно юеі̄ово у естетичком промеру самозаснивања човека као писца. И баш то је оно модернистички одлучујуће, јер искуство бистрине или изоштрености у самоодређењу преносом и чувањем језичког идентитета породице и заједнице (у његовој породици говорило се чистио српски), затим искуство померања којом непосредна егзистенција наплављује језичку осетљивост појединца (кретање од Темишвара до Београда и gаль) Црњански уграђује у једну естетички прворазредну и утемељујућу жељу: да се од једног 
већ многоспецификованог језика направи нешто у књижевном смислу тично, да се у језику пунктуира, осигура и другим силама претпостави воља ӣuсuа. Континуитет језичке самосвести писца и дубинских, сједињујућих струја језичког зденца српске културе, сталност измештања као окосница историјског, а још важније, онтолошког разумевања живота, у биографији и литератури Црњанског, манифестна модерност, продуктивне претензије писца на медијум и залом који снажна ауторска поетика представља у култури грађеној у том медијуму и оној која тај медијум изграђује као стандард властите репрезентације обриси су неуклоњиве, трајно маркантне и нестишано субверзивне појаве Милоша Црњанског и у историјскопоетичкој панорами српске књижевности и у репозиторијуму дијахроно-синхроних вредности српског језика. Црњански обележава искуство сталног кретања у језику, животу и вољи за писањем који су постали слободни елементи понекад уистину бесвесног догађања. Ови елементи и нису одражај нормативних кота културе, али у том бесвесном моменту, „када поезија говори” (Црњански 2004: 689), јесте једна кретња културе као такве, њеног говорења и разумевања, у којем није увек све извесно, али у којем јесте извесно и очигледно једно, премда тешко описиво, gаље. Даље и ка оном хоризонту у којем се окончава хуманистичко саморазумевање, под силином објективизације и са њом покренуте онтолошке промене субјекта. Али тада „пустите да вас носи језик, један занос језика који није нормалан, такорећи”, а „мећете тачке, и запете, доцније” (Црњански 2004: 689). Јер баш тада када човек о којем је прича престаје то да буде, постајући у једној реченици од субјекта објектом, нешто ипак преостаје, као занос језика, као поезија, што и за биће које у роману нестаје, као и за бића ван романа, за културу једног народа, представља један неупоредив траг. Знак естетике, књижевно- 
сти, језика, осећања, смисла, човека. У једној реченици знак свести о човековом нестанку и зато знак за човека. У тој реченици једна национална култура, њен језик, као са највишег врха, разумеју сваког човека овог света. Као што у тој реченици и он може разумети ову културу, свом самоосећању придружити и знак њеног, српског језика. Српску књижевност.

\section{Извори}

Црњански 2004: М. Црњански, Роман о Лонgону, приредио Мило Ломпар, Београд: НИН, Завод за уџбенике и наставна средства.

\section{Литература}

Бодријар 1991: Ž. Bodrijar, Fatalne strategije, prevod sa francuskog Mihailo Vidaković, Novi Sad: Književna zajednica Novog Sada. Ломпар 2008: М. Ломпар, На субверзивној десници, разговор са Милом Ломпаром, разговор водио Драган Бошковић,

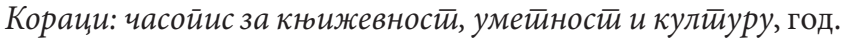
42, св. 11/12, Крагујевац: Културно-просветна заједница општине Крагујевац, Крагујевац, 175-194.

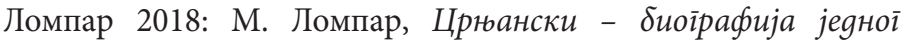
осећань, Нови Сад: Православна реч.

Петковић 1996: Н. Петковић, Лирске ейифаније Милоша Црюанскої, Београд: Српска књижевна задруга.

Принс 2011: Dž. Prins, Naratološki rečnik, prevela s engleskog Brana Miladinov, Beograd: Službeni glasnik.

Успенски 1979: B. Uspenski, Poetika kompozicije; Semiotika ikone, Beograd: Nolit. 


\section{Časlav V. Nikolić}

\section{SERBIAN LANGUAGE CAN SPEAK: LITERARY LANGUAGE FORMULATION IN THE NOVEL ABOUT LONDON BY MILOŠ CRNJANSKI}

Although, like other representatives of avant-garde modernism, he problematizes the linguistic norm, Miloš Crnjanski expresses in his narrative expression some very particular values. When in 1918, in a letter to Julije Benešić, he intended to mix elements of different dialects in his language so that no variant would be dominant, Crnjanski outlined the idea of a more comprehensive synthesis that would carry out historical, cultural, thematic and stylistic deepening and rounding and by which one would establish his or her own literary language in aesthetic, meta-lingual, semiotic-symbolic rather than normative design. We regard language in the Novel about London as one expression of the epochal maximum to which the Serbian language and the sensibility of Serbian culture have developed. As an example of this development, we recognize the specific dynamics in Crnjanski's narration according to which the syntactic and ontological positions of the subject and object in the same sentence are transformed into functions, so the subject becomes an object, while the object is transformed into a subject. In sentence dynamism, one can notice exactly what is the subject of Miloš Crnjanski's latest novel: the city empties as a subject and puts beings under its authority, beings who, without recognizing the ontological direction of their metamorphoses, are transformed into objects. Crnjanski's storytelling marks the experience of permanent movement and change in language, which is a reflex of change in contemporary experience. In order for the ontological and syntactic change of the subject to be expressed, it is necessary to have a specific feeling and to achieve a specific state of the language: a passion of language, which is not subject to the norm, but in which a trace of what disappears is visible. Which is also the a sign of what is gone, as well as the sign of literature itself and its language, which preserve what is disappearing in the world, as humanity.

Key words: language, literature, norm, subject, object, sentence, story 